DOI: http://dx.doi.org/10.33846/hn40305

http://heanoti.com/index.php/hn

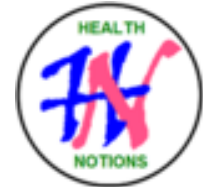

RESEARCH ARTICLE

URL of this article: http://heanoti.com/index.php/hn/article/view/hn40305

\title{
In Vitro Anthelmintic Activity of Acalypha Indica Leaves Extracts
}

\author{
Diah Titik Mutiarawati ${ }^{1(\mathrm{CA})}$ \\ ${ }^{1(\mathrm{CA})}$ Medical Laboratory Department, Poltekkes Kemenkes Surabaya; diahtitikmutiarawati@gmail.com \\ (Corresponding Author)
}

\begin{abstract}
Anting-anting leaves (Acalypha indica $\mathrm{L}$ ) is one of the wild plants (weeds) that are often used by the community to treat helminthic diseases such as ascariasis, containing several potentially anthelmintic compounds, namely saponins, tannins and flavonoids. The purpose of this study was to determine the effect of giving Anting-anting leaf extract (Acalypha indica L) as an anthelmintic to the time of death of pork roundworms (Ascaris suum Goeze). The method in this study was pre-experimental with a post test only group design. The subjects of the study were Ascaris suum. The study was conducted at the Parasitology Laboratory of the Surabaya Polytechnic Health Medical Laboratory Technologist Department in December 2018 to May 2019. This study used 5 treatment groups, $0.9 \% \mathrm{NaCl}$ as negative control and $0.25 \%$ pirantel pamoate as positive control and $60 \%, 80 \%$ and $100 \%$. Data were analyzed using the Kolmogrov-Smirnov test, then the Kruskal-Wallis test was then continued using a Post-Hoc test to determine the difference in anthelmintic power of ear leaf extract of each concentration with positive control over the time of worm death. The average time of Ascaris suum worm death at a concentration of a concentration of $60 \%$ for 228.5 minutes, a concentration of $80 \%$ for 174 minutes, and a concentration of $100 \%$ for 92 minutes. So it can be concluded that the leaf extract of Acalypha L has an anthelmintic effect on the Ascaris suum worm.
\end{abstract}

Keywords: anthelmintic; Ascaris suum; anting-anting leaf

\section{INTRODUCTION}

Ascariasis is a disease caused by intestinal nematode parasites, Ascaris lumbricoides, which often occur in tropical and developing countries. The prevalence of diseases caused by roundworms (Ascaris lumbricoides) reaches $25 \%$ or 0.8 - 1.22 billion people from the total world population. ${ }^{(1)}$ This parasite is found cosmopolitically. In Indonesia, the prevalence of worms by Ascaris lumbricoides is still high at around $60-90 \%$. The high prevalence of helminthiasis is caused by several factors, one of which is hygiene and sanitation.

Factors of low levels of hygiene and sanitation, lack of application of healthy living, low socio-economic conditions and age are predisposing factors for the development of this disease. According to Carneiro ${ }^{(2)}$ this parasite is capable of infecting all ages, but ascariasis more often infects elementary school-age children and toddlers because awareness of personal hygiene is still lacking and the body's resistance is low.

This disease is one of the Soil Transmitted Disease because it requires soil as an egg development medium to be an infective form. ${ }^{(3)}$ Ascaris lumbricoides worms can harm the human body. In the amount of large, these worms can cause intestinal obstruction, reduced appetite, diarrhea, constipation, impaired absorption of nutrients, and disruption of child development, whereas in small amounts these worms rarely show symptoms and are only known after the worms come out of the patient's body or the discovery of eggs in feces. ${ }^{(4)}$ In the larval stage, this worm can also cause damage to organs, Ascaris lumbricoides larvae are able to migrate to various tissues in the body which can cause mild inflammation in the liver and Loeffler syndrome in the lungs, and can even cause intestinal obstruction in severe infections.

Some antihelmintics such as pirantel pamoate and mebendazole are used as the drug of choice for ascariasis, even sold on the market without having to use a prescription. ${ }^{(5)}$ However, synthetic antihelmintic 
sometimes causes side effects that interfere with sufferers. Pirantel pamoate which works by causing depolarization in worms can cause nausea, vomiting, and diarrhea ${ }^{(6)}$. While mebendazole can cause more severe side effects such as erratic migration. ${ }^{(7)}$ The use of this drug is also limited. Ascariasis sufferers who have liver or kidney abnormalities cannot use it because these antihelmintics are metabolized in the liver and excreted through the kidneys. In order to reduce the side effects of synthetic worm medicine, another alternative that is derived from natural ingredients is needed.

Therefore natural anthelmintics that are safe are needed. One plant that has the potential as a natural anthelmintic is an anting-anting plant. Based on a study conducted by Ranju et al. ${ }^{(8)}$ that Pheretima posthuma's worm paralysis activity occurred 10 minutes after administration of ethanol extract of Anting-anting leaves and died after 29 minutes at a concentration of $5 \%(100 \mathrm{mg} / \mathrm{ml}$ in $\mathrm{pp})$. Until now, there have been no studies that study the anthelmintic activity of this plant against parasitic worms in humans such as Ascaris lumbricoides, Oxyuris vermicularis and Ancylostoma duodenale.

Anting-anting (Acalypha indica Linn.) leaves that are very commonly found growing wild on roadside, grass fields and on mountain slopes ${ }^{(9)}$. The phytochemical content of dried Anting-anting plants has the benefit of treating therapeutic problems, one of which is anthelmintic ${ }^{(10)}$, and also mentioned in the research of Syahiran et al. ${ }^{(11)}$ that the leaves of Anting-antings- Anting-antings can be consumed orally as anthelmintic and are more often consumed because the amount is abundant and easily separated from plant parts rather than stems, roots and flowers.

According to Nahrstedt et al. ${ }^{(12)}$, some chemical constituents have been isolated from Acalypha indica, including kaempferol glycosides, mauritianin, clitorine, nicotiflorin and biorobin, tannins, pyranoquinolinone flindersin alkaloids. Its ethanol extract is known to contain polyphenols, flavonoids, monoterpenes, sesquiterpenes, steroids, triterpenoids and quinones ${ }^{(13)}$, also flavonoids, tannins, saponins and glycosides in ethanol extract Anting-antings and alkaloids in petroleum ether extract, acetone and methanol ${ }^{(14)}$.

Ascaris suum Goeze test material is used as a test animal, because Ascaris lumbricoides (L) has a lot in common with Ascaris suum (Goeze), as well as some properties such as way of life and breeding, the worms of this genus are the same ${ }^{(15)}$.

Based on the background above, it is necessary to study whether the effect of anting-anting leaf extract (Acalypha indica Linn) as anthelmintic to the time of death of Ascaris suum Goeze by in vitro.

\section{METHODS}

\section{Types of Research}

The type of research used is a pre-experimental study to determine the effect of anthelmintic effect of Anting-anting leaf extract (Acalypha indica) on the death of Ascaris worms in adults in vitro. The research design used was post-test only control group design.

\section{Material}

The test material used in this study was anting-anting leaves (Acalypha indica) obtained from the UPT Materia Medika Yard, Pesanggrahan Village, Kecamatam Batu, Batu City, East Java, which carried out the extraction process using $96 \%$ ethanol.

\section{Animals}

The test animals used were Ascaris suum worms which were still actively moving from Pegirian Slaughterhouse, Surabaya.

\section{Time and Place of Research}

The time needed to conduct this research was from December 2018 to May 2019. The research site used was the Parasitology Laboratory of Medical Laboratory Department, Poltekkes Kemenkes Surabaya.

\section{Data Collection}

This study used observational data collection techniques (direct observation), namely by observing the time of Ascaris suum worm death after the administration of anting-anting leaf extract (Acalypha indica) with 
concentrations of $60 \%, 80 \%$ and $100 \%$. Negative controls were conducted to determine the quality of the Ascaris suum worm samples used in this study.

\section{Manufacture of extracts}

Weighing 1000 grams of dried leaf powder and then inserting it into the maceration container and extracting it using the maceration method with $96 \%$ ethanol. Soaking dried leaf powder using $96 \%$ ethanol, covered with aluminum foil and left for $3 \times 24$ hours at room temperature. After $3 \times 24$ hours, the sample which has been immersed in $96 \%$ ethanol is carried out by the filtering process using filter paper. Maserate results were collected and concentrated using rotatory vacuum evaporator at a temperature of $50^{\circ} \mathrm{C}$ until concentrated extract was obtained. Leave the concentrated extract produced at room temperature until all ethanol solvents evaporate. Obtained $100 \%$ concentrated extract of Anting-anting leaves (Acalypha indica).

Anting-anting leaf extract (Acalypha indica) made concentrations of $60 \%$, and $80 \%$, with the need for thick extract volumes, $0.9 \% \mathrm{NaCl}$, and $0.1 \mathrm{~mL}$ Tween 80 as follows:

a. $60 \%$ concentration

b. Dissolve 12 grams of concentrated extract of leaf Anting-antings with $20 \mathrm{~mL} \mathrm{NaCl} 0.9 \%$

c. $80 \%$ concentration

d. Dissolving 16 grams of leaf extract Anting-antings with $20 \mathrm{~mL} 0.9 \% \mathrm{NaCl}$

\section{Observation of Anthelmintic Extract Effect}

Prepare a petri dish to be used for observing the anthelmintic effect. Fill each petri dish with a solution of Anting-anting extract (Acalypha indica) with a concentration of $60 \%, 80 \%, 100 \%$ negative control, and positive control. Negative control contains $0.9 \% \mathrm{NaCl}$ solution. Positive control contains a solution of $0.25 \%$ pirantel pamoate. Insert five Ascaris worms on each petri dish containing a solution of the extract of the Anting-anting leaf. Observing the movement of Ascaris worms every minute by touching the body of the Ascaris worm using anatomical tweezers. Record the time of Ascaris suum worm death after the death of all worms in each treatment.

\section{Data Analysis}

The data analysis technique used in this study was quantitatively taken from primary data, namely data obtained from observations of the Ascaris suum worm death and the time of Ascaris suum worm death after being treated with an anting-anting leaf extract (Acalypha indica) will then be processed using tables and graphs. The data obtained were analyzed using the Kolmogrov-Smirnov statistical test to determine the normality of the data and then proceed with the homogeneity test using the SPSS application. Based on the normality and homogenity test, data were analyzed using Kruskal-Wallis test with a confidence level of $95 \%$ or $\alpha=0.05$, then proceed using the test Post-Hoc to determine the difference in anthelmintic power of antinganting leaf extract (Acalypha indica) against the death of Ascaris suum worms in In Vitro.

\section{RESULTS}

From the data and results of research on the time of Ascaris suum worm death caused by anting-anting leaf extract (Acalypha indica) will be tested statistically using the non parametric test, the Kruskal-Wallis test.

Based on the results of the Kruskal Wallis test obtained a p-value of 0.000 , so there was a difference between the treatment groups one with the other treatment groups.

A multiple comparison test was performed using the Post-Hoc Test. Based on the results of multiple comparison tests using Post-Hoc this test produced a variety of p-values. The treatment group that had a p-value of $<0.05$ (the treatment group had a significant difference in value with the other treatment groups). Meanwhile, the treatment group that had a p-value of $>0.05$ (the treatment group does not have a significant difference in value with the other treatment groups).

Different treatment groups were concentrations of $60 \%, 80 \%, 100 \%$, positive controls and negative controls. 
Table 1. Time of death Ascaris suum Goeze (minute) based on the replication

\begin{tabular}{cccccc}
\hline & \multicolumn{5}{c}{ Time of death Ascaris suum Goeze (minute) } \\
\cline { 2 - 6 } Replication & \multicolumn{4}{c}{ Concentration of Acalypha indica leaves } \\
\cline { 2 - 6 } & $60 \%$ & $80 \%$ & $100 \%$ & $\begin{array}{r}\mathrm{K} \\
(+)\end{array}$ & $\begin{array}{c}\mathrm{K} \\
(-)\end{array}$ \\
\hline 1 & 300 & 172 & 89 & 60 & 7200 \\
\hline 2 & 277 & 179 & 95 & 60 & 7200 \\
\hline 3 & 268 & 163 & 98 & 60 & 7200 \\
\hline 4 & 269 & 182 & 86 & 60 & 7200 \\
\hline
\end{tabular}

\section{DISCUSSION}

Based on the results of the study in table 1, it can be seen that the average time of Ascaris suum worm death on anting-anting leaf extract concentration of $60 \%$ for 228.5 minutes, at a concentration of $80 \%$ for 174 minutes, and at a concentration of $100 \%$ the average time of death of the worm was 92 minutes. This shows that anting-anting leaf extract has an anthelmintic effect which is shown by the acceleration of the time of Ascaris suum worm death which is proportional to the increase in the concentration of the leaf extract of the antinganting which is the higher the concentration the faster the time of death of Ascaris suum.

Positive controls used in this study are one of the selected drugs for ascariasis, Pirantel Pamoat. The researcher used a $0.25 \%$ pirantel pyrantel which is equivalent to a single-dose tablet, which is $250 \mathrm{mg}$ per tablet. Pirantel pamoat as a positive control in this study caused worm death Ascaris suum after the 60th minute. The drug acts as a neuromuscular blocking agent that causes the release of acetylcholine and inhibition of cocinesterase resulting in spastic paralysis ${ }^{(16)}$. Pirantel pamoat used is in the form of tablets, so to get a concentration of $0.25 \%$, it is dissolved with aquadest as much as $100 \mathrm{~mL}$.

Negative control on this research was $\mathrm{NaCl} 0.9 \%$. The results showed that Ascaris suum worm death time with negative control of physiological $\mathrm{NaCl} 0.9 \%$ for 120 hours or about 5 days. $0.9 \% \mathrm{NaCl}$ was chosen as negative control. This is because this solution contains ions which are indeed needed by the worm's body for its physiological processes. In addition, this solution is a nutrient for the body of roundworms, so it does not damage the worm's body cell membranes.

The results obtained by the researchers used Anting-anting leaves extracted using ethanol solvents and test animals in the form of Ascaris suum, where the optimum concentration was $100 \%$ with an average length of death of all worms 92 minutes which was close to the length of death of all worms caused by positive control, namely pirantel pamoat. This can be caused other than because of the anthelmintic effect that comes from Anting-anting leaves as well because the method and solvent used are more specific in taking active substances in it, and the test animals used are different from previous studies.

The anthelmintic effect derived from Anting-anting leaves is due to the active content of saponins, tannins and flavonoids acting as anthelmintics as has been found from a previous study by Masih ${ }^{(17)}$ that the results of the phytochemical screening test, leaf Anting-antings (Acalypha indica L.) contains compounds including: alkaloids, flavonoids, and saponins.

The saponin compounds contained in the leaf extract of these Anting-antings are compounds in the form of glycosides. The mechanism of saponin compounds as anthelmintics is that it has the potential to kill worms because it works by inhibiting the acetylcholinesterase enzyme and irritating the mucous membranes, so that the worms will experience muscle paralysis and lead to death ${ }^{(18)}$.

While the mechanism of action possessed by tannins is by disrupting the worm's negative ion body charge into positive ions (protonization), which then attract positive worm body proteins in the gastrointestinal tract, thus disrupting the metabolism and homeostasis of the worm's body ${ }^{(19)}$.

In addition to saponins and tannins, there are flavonoids which support the acceleration of worm death. According to Ulya et al. ${ }^{(20)}$ the ability of flavonoids in anthelmintics, namely flavonoids that come in direct contact with the worm's body, will be quickly absorbed into the worm's body and will cause denaturation of proteins in the tissues causing death in worms. Therefore, in this study it can produce an acceleration in the time of Ascaris suum worm death followed by an increase in the concentration of anting-anting leaf extract. As for 
some advantages and disadvantages of the extraction method and infusa method, the extraction method is more specific in taking active substances. which is used as an anthelmintic but the disadvantage of this method is the expensive cost and length of time used. While the infiusa method has the advantage that the cost used is less and requires a short time but the disadvantage of this method is the amount of disturbing substances and infusion temperature which is maintained at $90^{\circ} \mathrm{C}$ where this temperature exceeds the optimal temperature limit for heating anthelmintic active substances. Where we know the active substances that work as anthelmintics have thermolable properties which are not resistant to high temperatures.

Table 1, it can be seen that the duration of Ascaris suum worm death caused by anting-anting leaf extract at a concentration of $100 \%$ has a time that is close to the time of worm death caused by Pirantel pamoat. Antinganting leaf extract has a high chance of being developed as an anthelmintic drug especially in ascariasis. Because, there is an acceleration in the time of Ascaris suum worm death caused by leaf extract of antingantings. In addition, the use of Pirantel pamoat has side effects in the form of indigestion, fever and headaches, which may not be found in the use of anting-anting leaf extract as a worm medicine because it comes from natural ingredients.

\section{CONCLUSION}

\section{Conclusion}

From the results of research on the anthelmintic effect of anting-anting leaf extract (Acalypha indica) on Ascaris suum worms, it can be concluded that the time of Ascaris suum worm death caused by anting-anting extract with $60 \%$ concentration on 228.5 minutes, $80 \%$ concentration on 174 minutes, and $100 \%$ concentration on 92 minutes. The long time acquisition of worm death caused by anting-anting leaf extract with a concentration of $100 \%$ has a longer worm death time with a long worm death caused by pantelate pyrantel as a positive control that is for 60 minutes. Ascariasis.

In this study, it was proven that Anting-anting leaf extract had an anthelmintic effect in the case of

\section{Suggestion}

1. Researchers are then expected to test the levels of active compounds in the extract of the Anting-anting act as anthelmintics and conduct anthelmintic tests on parts of the Anting-anting plant other than leaves.

2. For the community, they can use the part of the Anting-anting-antin leaf plant to be used as an alternative treatment for Ascariasis disease and make processed products for Anting-anting leaves.

\section{REFERENCES}

1. David RH. Ascariasis. Medscape; 2018.

2. Carneiro FF, Cifuentes E, Tellez-Rojo MM, Romieu I. The risk of Ascaris lumbricoides infection in children as an environmental health indicator to guide preventive activities in Caparao and Alto Caparao, Brazil. Bulletin of the World Health Organization. 2002;40-46.

3. Sudoyo WA, Setyohadi B, Alwi I, Setiasi S. Ilmu Penyakit Dalam. Jakarta: Department of Internal Medicine, FKUI; 2006.

4. Kazura JW. Nematode Infections. Philadelphia: Saunders Elsevier; 2007.

5. Syarif A, Elysabeth. Anthelmintic in Pharmacology and Therapy (Antelmintik Dalam Farmakologi dan Terapi). Jakarta: Department of Pharmacology and Therapeutics, Faculty of Medicine, Universitas Indonesia; 2006.

6. Urbani C, Albonico M. Anthelminthic Drug Safety and Drug Administration in the Control of SoilTransmitted Helminthiasis in Community Campaigns. Acta Trop. 2003;215-222.

7. Albonico M, Allen H, Chitsulo L, Engels D, Gabrielli. Controlling Soil-Transmitted Helminthiasis in PreSchool-Age-Children through Preventive Chemotherapy. PLOS Neglected Tropical Disease. 2008.

8. Ranju G, Niranjan S, Kumar PS, Kumar PV, Kumar PS. Invitro Anthelmintic Activity of Acalypha indica Leaves Extracts. IJRAP. 2017;247-149.

9. Kawatu CB, Mongi J. Test on the Effect of Ethanol Extract of Anting-anting Leaf (Acalypha indica L.) on Blood Sugar Levels of Male White Mouse Wistar (Rattus novergicus) (Uji Efek Ekstrak Etanol Daun Anting-Anting (Acalypha indica L.) Terhadap Kadar Gula Darah Tikus Putih Jantan Galur Wistar (Rattus novergicus). Pharmacon. 2013;81-85. 
10. Mohan C, Dinakar S, Anand T, Elayaraja R, SathiyaPriya B. Phytochemical , GC-MS Analysis And Antibacterial Activity of A Medicinal Plant Acalypha indica. International Journal Pharmaceutical Technology Research. 2012;1050-1054.

11. Syahiran N, Zulkifli R, Saidin S, Muhamad II. A Review of Acalypha indica L (Euphorbbiaceae) as Tradition Medical Plant and Its Therapeutic Potential. Journal of Ethnopharmacology. 2016.

12. Nahrestedt A, Hungeling M, Petereit F. Flavonoids from Acalypha indica. Institute of Pharmaceutical Biology and Phytochemistry. 2006;484-486.

13. Febriyanti M, Supriyatna, Abdullah R. Chemical content and cytotoxic activity of extracts and fraction of herbal anting-anting (Acalypha indica Linn) against breast cancer cells MCF-7 (Kandungan Kimia dan Aktivotas Sitotoksik Ekstrak dan Fraksi Herba Anting-Anting (Acalypha indica Linn) terhadap Sel Kanker Payudara MCF-7). Jurnal Darmasi Indonesia. 2014;19-26.

14. Vijayarekha P, Sangottaiyan N, Noorjahan A, Ambiga S. Antibacterial Activity of Acalypha indica Linn. International Journal of Current Microbiology and Applied Science. 2015;1133-1138.

15. Mia ZR. The ultrastructural morphology of A.suum and A. lumbricoides worm eggs by the scanning electron microscope (SEM) method. Laboratory Explorative Research (Morfologi ultrastruktur telur cacing A. suum dan A. lumbricoides dengan metode scaning electron microscope (SEM). Penelitian Eksploratif Laboratoris). Surabaya: Universitas Airlangga; 2015.

16. MoH-RI. Regulation of the Minister of Health of the Republic of Indonesia Number 15 of 2017 concerning Worm Management (Peraturan Menteri Kesehatan republik Indonesia Nomor 15 Tahun 2017 tentang Penanggulangan Cacing). Jakarta: MoH-RI; 2017.

17. Masih M, Banerjee B, Pal A. Antidiabetic Activity of Acalypha indica Linn on Normal and Alloxan Induced Rats. International Journal Pharmaaceutical Science. 2011;51-54.

18. Intannia D, et al. The Influence of Ethanol Extract and n-Hexane Extract of Chinese Ketepeng Leaves (Cassia Alata. L) on the Time of Death of Chicken Tapeworms (Raillietina Sp.) In Vitro (Pengaruh Pemberian Ekstrak Etanol dan Ekstrak n-Heksan Daun Ketepeng Cina (Cassia Alata. L) Terhadap Waktu Kematian Cacing Pita Ayam (Raillietina Sp.) Secara In Vitro). Jurnal Pharmascience. 2015;2(1).

19. Himawan VB, Endharti AT, Rahayu ID. Antihelmintic Test of Papaya Leaf Decoction (Carica papaya L.) Against Ascaris suum In Vitro (Uji Daya Antihelmintik Dekok Daun Pepaya (Carica papaya L.) Terhadap Ascaris suum Secara in Vitro). Majalah Kesehatan. 2015.

20. Ulya N, Endharti AT, Setyohadi R. Anthelmintic Test of Ethanol Extract of Cat Whisker Leaves (Orthosiphon aristatus) as Anthelmintic Against Ascaris suum in Invitro (Uji Daya Anthelmintik Ekstrak Etanol Daun Kumis Kucing (Orthosiphon aristatus) Sebagai Anthelmintik Terhadap Ascaris suum Secara Invitro. Majalah Kesehatan FKUB. 2014;1(3). 